Vol. 1 No. 02 Hal. 16 - 19

September 2018

\title{
Kompetensi Pedagogik Guru Profesional
}

\author{
Hasrita Lubis \\ Dosen PNS Kopertis Wilayah I Sumatera Utara DPK UISU \\ Hasrita_lbs@yahoo.com
}

\begin{abstract}
ABSTRAK
Kompetensi Pedagogik adalah kemampuan dasar yang harus dimiliki seorang Guru Profesional. Kompetensi paedagogik merupakan praksis perilaku kinerja guru dalam proses pembelajaran. Perilaku kerja guru dalam proses pembelajaran dilandasi demgam pijakan teoretis kompoen kompetensi paedagogik sebagai berikut : karakteristik peserta didik, teori belajar dan prinsip-prinsip pembelajaran yang mendidik, Pengembangan kurikulum, Kegiatan pembelajaran yang mendidik dan pengenbangan potensi peserta didik peserta didik dapat mengaktualisasikan potensinya seoptimal mungkin melalui proses pembelajaran.
\end{abstract}

\section{ABSTRACT}

Pedagogic Competence is the basic ability that must be possessed by a Professional Teacher. Paedagogic competence is the praxis of teacher performance behavior in the learning process. Teacher's work behavior in the learning process is based on the theoretical basis of kompoen paedagogic competence as follows: learner characteristics, learning theory and the principles of learning that educate, curriculum development, learning activities that educate and develop the potential of learners can actualize their potential optimally through learning process.

\section{PENDAHULUAN}

\section{Latar Belakang}

Secara nasional kompetensi guru dicanagkan dalam undang-undang guru dan dosen No:14 tahun 2005. Kompetensi pekerjaan profesional telah di mulai pekerjaan profesional lainnyaseperti ptofesi dokter, hukum, akuntasnsi dan pekerjaan profesinal lainnya. Kompetensi dan pekerjaan profesional memiliki hubungan yang sangat bermakna dalam bentuk kualitas kenerja. Masalah yang timbul dalam kinerja guru dan dosen berhubungan langsung dengan harapan masyarakat pengguna. Masyarakat merasa kecewa bila profesi guru tidak menunjukkan kinerja profesional. Proses mendidik yang dilakukan guru dinilai masyarakat secara berkelanjutan. Maka calon guru dipersiapkan sejak dini dengan empat kompensi yaitu kompetensi Spritual/kepribadian, kompetensi, paeagogik, kompetensi sosial/pisikologi dan kompetensi profesional yang harus dimiliki guru profesional. Salah satu kopetensi adalah kompetensi paedagogik. Kompetensi paedagogik mencakup kemampuan guru dalam mengelola proses pembelajaran siswa dan mengembangkan potensi siswa secara optimal. meningkatkan kesejahteraan Sertifikasi guru bertujuan untuk memperbaiki kualitas dan kesejahteraan guru. Kualitas guru dititik beratkan pada proses pembelajaran agar capaian pembelajaran dikuasai pederta didik secara maksimal sesuai potensi yang dimilikinya. Kompetensi Pedagogik merupakan salah satu kompetensi yang mutlak perlu dikuasai guru karena kompetensi paedagogik hakikatnya kemampuan guru dalam mengelola pembelajaran peserta didik. Kompetensi Pedagogik merupakan kompetensi unik, yang akan membedakan keunikan profesi guru dengan profesi lainnya . 
kompetensi akan menentukan tingkat keberhasilan proses dan capaiam pembelajaran peserta didik. Pertanyaanya apakah semua guru mampu mengimplementasikam kompetensi paesagogik sehingga tidak ada lagi guru yang menunjukkan kinerja yang menggenaskan masyarakat.

\section{II.KARAKTERISTIK PESERTA DIDIK}

Karakteristik peserta didik memcakup seliruh indikator ysng berkaitan dengan aspek diri peserta didik berkaitan aktivtas proses pembelajaran. Guru membangun profesionalitas pembelajarammya dengan mengimplementasikan seluruh komponan kompetensi paedagogik. Apakah semua guru dapat membangun kemampuannya menjadi guru profesional yang mendidik peserta didiknya berdasarkan dengan mengiplementasikan kompetensi paedagogik. Menguasai karakteristik peserta didik adalah indikator kompetensi paedagogik yang utama. Guru memiliki kemampuan mengidentifikasi segala informasi pelajar dengan mencatat dan menggunakan informasi tentang karakteristik peserta didik untuk membantu proses pembelajaran (Suyanto:2013). Karakteristik ini terkait dengan aspek fisik, intelektual, sosial, emosional, moral, dan latar belakang sosial budaya: ada pun indikator kinerja yang dapat ditunjukkan guru untuk mengenal karakteristik peserta didik adalah sebagai berikut : (1)Mengidentifikasi karakteristik belajar setiap peserta didik di kelasnya, karakteristik proses pembelajaran pelajar diidentifikasi mencakup siswa yang mampu belajar dengan cepat, sedang dan peserta didik belajar lambat. (2) Secara pasti mengumpul data bahwa semua peserta didik mendapatkan kesempatan yang sama untuk berpartisipasi aktif dalam kegiatan pemmengelola pembelajara. (3) Mengelola kelas untuk memberikan kesempatan belajar yang sama pada semua peserta didik dengan kelainan fisik dan kemampuan belajar yang berbeda, (4) Memiliki data yang lengkap tentang pemyimpangan perilaku belajar peserta didik (5) Guru membantu mengembangkan potensi dan mengatasi kekurangan peserta didik dalam merancang masa depan yang diinginkan peserta didik. (6)Mampu memberi layanan penbekajaran kepada peserta didik yang menyandang kelemahan fisik tertentu sehingga dapat mengikuti aktivitas pembelajaran dan potendi yng dimiliki berkembang sedaram optomal, (7) Menguasasi Teori Pembelajaradan mahir dakam memoeraktekka prinsip-prinsip pembelajaran yang mendidik. Guru mampu menetapkan berbagai pendekatan, strategi, metode, dan teknik pembelajaran yang mendidik secara kreatif sesuai dengan standar kompetensi guru. Guru mampu menyesuaikan metode pembelajaran yang sesuai dengan karakteristik peserta didik dan memotivasi mereka untuk belajar: (8) Beruaaha smemastikan tingkat pemahaman peserta didik terhadap materi pembelajaran tertentu dan menyesuaikan aktivitas pembelajaran berikutnya berdasarkan tingkat pemahaman tersebut, (9)Menggunakan berbagai teknik untuk memotiviasi kemauan belajar peserta didik. (10) Merencanakan kegiatan pembelajaran yang saling terkait satu sama lain, dengan memperhatikan tujuan pembelajaran maupun proses belajar peserta didik. (11) Melayani peserta didik dalam bentk layanan segera atau remedial untuk yang belum/kurang memahami materi pembelajaran yang diajarkan dan menggunakannya untuk memperbaiki rancangan pembelajaran berikutnya. Melatih diri menjadi guru profesiunal guru senantiasa me;akukan identifikasi karanter peserta didik dan mengadministrasikannya secara lengkap dan sahih hingga semua pesertadidik memiki data informasi untuk memperoleh kesempatan dalam mengembangkan potensinya. Berdasrkan data base yang lengkap guru dapat mengelola kelas dengan pemetaanyang sesuai hingga peserta didik berfikir positif tentang dirinya. Guru juga memiliki data yang akurat tentang kelemehan belajar yang dimiliki peserta didik dapat dijadikan guru sebagai landasan membuat rancangan pembelajaran berasaskan teoretis mrmberika bantuan layanan belajar, peserta didik yang mengalami gangguan belajar. Peserta didik mendapat bantuan khusus dalam 
pembejaran dalam merancang masa depannya sesuai potensi yang dimilikinya. Guru menggunakan pendekatan dan metode yang berpariasi hingga secara pasti memahami batas penguasaan peserta didik terhadap materi untuk dilanjutkan proses pembelajrannya sampai tuntas.selanjtnya guru memberikan layan segera kepada peserta didik hinga peseta didik tidak merasa ada terbebani dengan kesu;itan belajar ketika dia meningglkam kelas (Sagala;2013).

\section{III.PENGEMBANGAN KURIKULUM}

Perubahan kurikumum terjadi secara nasional nanun muatan lokal tetap menjadi bahan yang urgen dengan kepentingan otonomi dan pengembangan potensi peserta didik. Guru yag profesional memiliki kearifan untuk menggali potensi budaya daerah dengan kecerdasan spritual yang tinggi. Nilai karakter bangsa dengan adab yang mulia menjadi materi utama dalam mengembangkan kurikulum, rasa kemanusiaan, sikap gotong royong, mencapai kesejagteraan yang berkeadilan merupakan materi unggulan yang akan menjadi dasar mengembangkan kurikulum.Guru mampu menyusun silabus sesuai dengan tujuan terpenting kurikulum dan menggunakan RPP sesuai dengan tujuan dan lingkungan pembelajaran. Guru mampu memilih, menyusun, dan menata materi pembelajaran yang sesuai dengan kebutuhan peserta didik. Secara (al-TabanyL2014_terperinci komponen kompetensi guru dalam mengembangkan kurikulum adakah sebagai berikut: (1)Guru merancang rencana pembelajaran yang sesuai dengan silabus untuk membahas materi ajar tertentu agar peserta didik dapat mencapai kompetensi dasar yang ditetapkan. (2)Mengikuti urutan materi pembelajaran dari yang tingkat kesulitan rendah menuju lebih tinggi dengan memperhatikan tujuan pembelajaran, (3)Memilih materi pembelajaran yang: (i) sesuai dengan tujuan pembelajaran, (ii) tepat dan mutakhir, (iii) sesuai dengan usia dan tingkat kemampuan belajar peserta didik, (iv) dapat dilaksanakan di kelas dan (v) sesuai dengan konteks kehidupan sehari-hari peserta didik. Kemampuan guru dalam merancang pembelajaran untuk mencapai standar kompetensi lulusan dengan aneka bahan ajar yang bepariasi akan melahirkan peserta didik yang unggul dalam berkreasi. Tingkat kesulitan materi dakam kerangka kurikulum nasional Indinesia menantang kemampuan guru dalan memperkaya bahan ajar.Tingkat kesulitsn materi dslsm urutsn jenjang dan jenis pendidikan mwrupakan profesional guru dalam menganakisis capaian kompetensi lulusan. Guru yang profesional akan mengasah kemahirannya secara berkelanjutan dalam meng update materi terkini yang rasional dan menerik minat dan cita0cita masa depan peserta didik yang terlahir secara alamiah.

\section{IV.KESIMPULAN}

Kegiatan penbelajaran yang menddidik adalah unjuk kerja guru yang menunjukkan kemamampuan menyusun dan melaksanakan rancangan pembelajaran yang mendidik secara lengkap. Guru mampu melaksanakan kegiatan pembelajaran yang sesuai dengan kebutuhan peserta didik dalam mengembangkan potensinya secara optimal. Guru mampu menyusun dan menggunakan berbagai materi pembelajaran dan sumber belajar sesuai dengan karakteristik peserta didik. Jika relevan, guru memanfaatkan Teknologi Informasi Komunikasi (TIK) untuk kepentingan pembelajaran seperti berikut: (1)Melaksanakan aktivitas pembelajaran mengikuti rancangan yang telah disusun secara lengkap dan pelaksanaan aktivitas tersebut menunjukkan bahwa guru mengerti tentang tujuan/capaian pembelajaran, (2) Melaksanakan aktivitas pembelajaran tujuanya untuk membantu/mendampingi proses pembelajaran peserta didik, bukan untuk menguji sehingga membuat peserta didik merasa tertekan, (3)Mengkomunikasikan informasi baru (misalnya materi tambahan yang tingkat kesulitannya sama) sesuai dengan usia dan tingkat 
kemampuan belajar peserta didik, (4)Menyikapi kesalahan yang dilakukan peserta didik sebagai tahapan proses pembelajaran, bukan bermaksud menunjukkan kesalahan yang harus dikoreksi. Misalnya: dengan mendiskusika terlebih dahulu dengan eserta didik lain himgga ditemukan kesalahan yang harus diperbaiki dengan dan ditemukan jawaban yang benar secaea bersama-sama.(5)Melaksanakan kegiatan pembelajaran sesuai isi kurikulum dan mengkaitkannya dengan konteks kehidupan sehari-hari peserta didik, (6)Melakukan aktivitas pembelajaran secara bervariasi dengan waktu yang cukup untuk kegiatan pembelajaran yang sesuai dengan usia dan tingkat kemampuan belajar dan mempertahankan perhatian peserta didik, (7)Guru mengelola kelas dengan efektif tanpa mendominasi atau sibuk dengan kegiatannya sendiri agar semua waktu peserta dapat termanfaatkan secara produktif dari awal hingga akhir proses pembelajaran., (8)Mampu menggunakan audio-visual (termasukTIK) untuk meningkatkan motivasi belajar peserta didik dalam mencapai tujuan pembelajaran. Menyesuaikan aktivitas pembelajaran yang dirancang dengan iklim kelas, (9)Memberikan banyak kesempatan kepada seluruh peserta didik untuk bertanya, mempraktekkan dan berinteraksi dengan peserta didik lain, (10)Mengatur pelaksanaan aktivitas pembelajaran secara sistematis untuk membantu proses belajar peserta didik. Sebagai contoh: guru menambah informasi baru setelah mengevaluasi pemahaman peserta didik terhadap materi sebelumnya, dan (11)Menggunakan alat bantu mengajar, dan/atau audio-visual (termasuk tik) untuk meningkatkan motivasi belajar pesertadidik dalam mencapai tujuan pembelajaran. (12)Rancangan pembelajaran yang di susun guru yang profwsional telah memprediksi capaian pembelajaran bersasarkan identifikasi karakter seluruh peserta didik dikelas. Kesempatan belajar bagi seluruh peserta didik uktuk mengesistensikan potensinya telah diperkirakan guru berdasarkan identifikasi karakteristik peserta didik decara berkelanjutan (Prayitno"2013) . Kemampuan belajar peserta didik dari berbagai tingkatan akan mendapat peluang yang sama nengembangkannya, peserta didik yang lambat dalam proses pembelajaran tidak akan merasa tertekan karena peserta didik merasa yakin didampingi oleh gurunya sampai capain pembelajaran yang direncanakan itu tercapai. Guru juga memberikan pengayaan dengan timgkat kesulitan yang sama ataupun tingkat kesulitanyang lebih tinggi. Dalam mencapai pembelajaran yang efektif guru menggnakan audio visual dengan kelas yang dikelola secara kondusif hingga iswa mendapat kesempatan yang luas bagi peserta didik untuk bertanya, memperaktekkan dan berinteraksi sesana tenan belajarnya. Dari uraian di atas dapat disimpulkan bahwa kompetensi paedagogik merupakah praksis kinerja guru dalam melaksanakan proses pembelajaran. Guru yang profesional memulai karirnya dari calon guru dan guru pemula telah memperaktekkan kompetensi paedagogik menuju mahir mengimplementasikan seluruh item-item kompetensi paedagogik dalam proses pembelajaran yang dilakukannya.

\section{DAFTAR PUSTAKA}

al-Tabany.2014. Mendesain Pembelajaran Inovatif dan Konstektual. Jakarta: Pranada.

Prayitno, Mungin Eddy Wibawo. Marjohan, Heru Mugiarso. 2013. PembelajaranMelalui Pelayanan BK di Satuan Pendidikan,

Sagala. 2013. Etika Moralitas Pendidikan. Jakarta Prenada

Suyanto. 2013. Menjadi Guru Profesional. Jakarta Prenada 